\title{
PECULIARITIES OF INNOVATIONS IMPLEMENTATION ON THE UKRAINIAN BRAND EXAMPLE
}

\author{
Nataliia Letunovska; Hanna Voda; Svitlana Kadurina; Anna Tsunenko
}

\author{
Sumy State University, Sumy, Ukraine
}

\begin{abstract}
Summary. In this paper, the authors proposed their own idea of innovative sweatshirt that can be developed and introduced into the national market for young clothing brand VOVK. The target of the investigation is the creation of the new innovative product in youth clothes segment focused on national fashion market. The research target is chosen for a good reason since there are contradictions in this segment, such as supply and demand disproportion. The Ukrainian young people need really fashionable, high-quality and interesting clothes from national manufacturers, so they have to buy foreign substitute goods. The national manufacturer losses its profit. The authors meaningfully and by stages highlight the organizational and economic peculiarities of innovation development - from the distinct problem vision solved by this product to the latest trends in the world fashion culture that make the proposed solution possible. The project competitors among the clothes manufactures in Ukraine are analyzed. The technological solution and marketing parameters of the future supply (target audience, pricing approaches, methods of product promotion, etc.) are described. Planned efficiency indices for this project are calculated. The evaluation of potential risks and the level of their impact on the project as a whole is carried out. The carried out investigation and its visual representation is relevant for entrepreneurs engaged in tailoring and promoting their own brands in the Ukrainian market, for people interested in fashion market innovations, as well as for researches analyzing determinants and imperatives of the national innovative economy development
\end{abstract} audience.

Key words: fashion innovation, Ukrainian brand, innovation project, economic effectiveness, target

\section{УДК 339.138:005.521:796.332}

\section{ОСОБЛИВОСТІ ВПРОВАДЖЕННЯ ІННОВАЦЙ НА ПРИКЛАДІ УКРАЇНСЬКОГО БРЕНДУ}

\section{Наталія Летуновська; Ганна Вода; Світлана Кадуріна; Світлана Цуненко}

\author{
Сумський державний університет, Суми, Украӥна
}

\begin{abstract}
Резюме. Запропонувано власну ідею інноваціійного світшоту, яку можна запропонувати ринку вітчизняному молодому бренду одягу «VOVK». Об' єктом дослідження є процес створення інноваційного продукту в сегменті молодіжного одягу, орієнтованого на вітчизняний ринок моди. Об'єкт дослідження обраний не випадково, оскільки в иььму сегменті є суперечності, а саме: дисбаланс попиту та пропозиціі. Українській молоді не вистачає дійсно модних, якісних та цікавих речей від вітчизняних виробників, тому їм доводиться купувати зарубіжні замінники. Вітчизняний виробник втрачає від цьього прибуток. Автори змістовно та поетапно висвітлюють організаційні та економічні особливості інноваційного розвитку від формування чіткого бачення проблеми, яка вирішується за допомогою цьього продукту, до останніх тенденцій світової культури моди, які роблять можливим запропоноване рішення. Проаналізовані конкуренти проєкту серед виробників одягу в Украӥні. Описане технологічне рішення та маркетингові параметри майбутнього постачання (цільова аудиторія, підходи до ціноутворення, методи просування товару тощяо). Розраховані планові показники ефективності проєкту. Здійснено оцінювання потенційних
\end{abstract}


ризиків та рівня їх впливу на проєкт у цілому. Проведене дослідження та його візуальне представлення можуть бути корисними для підприємџів, які займаються пошиттям одягу та просуванням власних брендів на українському ринку, людям, які цікавляться новинками на ринку моди, а також тим досліднкам, які займаються аналізом детермінант та імперативів інноваційного розвитку нащіональної економіки.

Ключові слова: інновачія в сфері моди, украйнський бренд, інноваційний проєкт, економічна ефективність, ичільова аудиторія.

Introduction. The Ukrainian fashion market is developing rapidly. Women's clothing is the most in demand. For these reasons, we have selected a typical representative of the market, a manufacturer of women's clothing line VOVK company. According to the results of 2018 this brand is among the leaders in the list of the most popular clothing manufacturers in Ukraine. In just 8 years of activity of this brand, it became popular in 17 Ukrainian cities, including Kyiv, other millionaire cities and regional centres. The authors propose innovative project - unique sweatshirts with interesting colour variation technology during the changing weather conditions. The authors drew attention to VOVK brand because it stands out among other bright colours, prints and high quality, which are the main factors for the creators of clothing. In addition, it is not an expensive brand, and therefore it can be afforded by progressive but not wealthy young people. In today's domestic fashion, this brand is more relevant than ever at Made in Ukraine. In general, the authors evaluate the activity of the analyzed company in order to show through its example how it is possible to add a new potentially profitable product position to the assortment of the existing company at the market and what are the main points of its activity in the development of innovation in the fashion market it is advisable to focus on.

Analysis of the available researches and publications. While searching for an idea of an innovative product and choosing an area of activity in which it is advisable to introduce something new, the authors analyze a number of useful sources, modern literature regarding the experience to implement other startups in the Ukrainian market and abroad. Among such sources of literature, there are popular editions [1-6], as well as online sources. Therefore, for example, the description of the original clothing from the company «Aerochromics» was used to form the idea of an innovative sweatshirt, which the authors of the work have found out while surfing the Internet [7].

Innovation in the field of fashion in Ukraine attracts a number of popular scientists, such as I. A. Gardabhadze [8], Yasinska O. G. [9], Chuprina N. V. [10], Bondarenko S. M. [11], etc., but they pay much attention to theoretical and methodological approaches to the fashionable goods market segmentation, marketing approaches to the promotion of fashion products in the market, various aspects of management in the fashion sphere in bringing products from the manufacturer to the end-consumer. Therefore, the authors also consult for such unscientific sources, namely articles in online magazines about the entrepreneurs' success stories in the field of fashion and design of wardrobe items, among which there are representatives of the domestic fashion world from the authors' home country clothing brands «Komashnya», «Tell», «Petro Soroka», «Rosmova».

An analysis of such a variety of information sources has shown that the fashion market is very changeable. Consumers require new offers from clothing manufacturers. Success is achieved by those entrepreneurs who are not afraid to take risks, bring their market innovations to the market and gradually turn them into casual clothes of Ukrainians in case of their successful commercialization.

The objective of the investigation is formed by the authors as a narrower part of the analyzed problem, namely the process of creating an innovative product in the youth clothing segment, which is oriented towards distribution within the domestic fashion market. The subject 
of the author's research is the modern fashionable clothing market, including such segment as a clothing item for young people seeking to stand out from the crowd. The research object is chosen not by accident since there are contradictions in this segment, namely the supply and demand imbalance. The Ukrainian youth lacks really fashionable, high-quality and interesting things from native manufacturers, so they have to buy substitutes (Chinese, Turkish, Polish wares). The domestic manufacturer suffers from it receiving less profit.

Basic material. Today's youth try constantly to stand out from the crowd, to emphasize their uniqueness and personality, which is not always possible. Therefore, boys and girls are constantly looking for things that can help solve this problem. Young people are actively following the changes in fashion trends, subscribing to different bloggers and watching their lifestyle, seeking to be like them. When trying to stand out from their peers, young people keep up with the latest innovations. One way to solve the problem of uniqueness is to buy branded, modern clothing.

Recently, the sweatshirt has become popular. The sweatshirts are in demand, have different colours, any lettering and images. They can suit any person. Sweatshirts with interesting and unusual drawings, which are designed to dilute the boring routine, are very popular today. Young people are happy to wear sweatshirts to study, parties, work etc. This clothing item fits perfectly with any outfit and complements the look. Thus, every fashionista knows that the sweatshirt is necessary basic clothing.

As for the company Vovk, sweatshirts are in the product range of this entity but the number of varieties of them is quite small (Figure 1). The introduction of product innovations will increase the demand for the company's products and attract the consumers' attention.

We propose to produce and to sell sweatshirt under the trademark «VOVK». The peculiarity of the product is the change of colour depending on weather conditions. Consumers can know in advance what the weather is expecting: if sunny, the colour of the clothing will change to warm shades (yellow, orange, mustard, light pink, brown, light green, red) and to cool shades if the weather is cloudy (blue, purple, burgundy, dark green). Rainfall (rain, snow, hail) will cause the sweatshirt to be black or grey. Clothing will be made of a fabric that does not let moisture. The sweatshirt will be powered by a mobile application on a smartphone, thanks to Bluetooth connectivity and geolocation, recharge via USB cable and charger for 24 hours. A warranty card will be added to the product, which will give you the right to replace or repair the light in case of malfunctions. The item will be valuable to the consumer because it has unique properties and has no analogues on the market. It will enable its owners to stand out from the crowd and attract the others' attention. The proposed sweatshirts can be worn in everyday life, as well as at various parties. Such sweatshirts will be perfect on modern dance shows. The clothing of Aerochromics was used to create an innovative sweatshirt. The main feature of Aerochromics clothing is its sensitivity to harmful contaminants in the air. According to the manufacturers, when the concentration of dangerous substances in the air exceeds the norm, the T-shirt changes its colour, showing a geometric pattern, indicating that the level of pollution is exceeded in the air. Each model has its own technology. For example, a T-shirt for detecting harmful particles has two built-in sensors on the chest and back, respectively, they are connected to special heat panels to change the colour of the fabric. At the same time, special carbon strips are used in the carbon monoxide model, which changes colour from black to white if it comes in contact with gas. According to the technology of production, the sweatshirts will be similar to the idea of the Ukrainian startup of PIX-backpacks - a smart animated backpack, which is equipped with a built-in LED display of 16.5 million colours, the appearance of which can be controlled using a smartphone [12]. The Product Development Roadmap (Figure 2) includes a number of indicative steps. At each stage, there is an improvement of the clothes properties and the technologies of their production. 


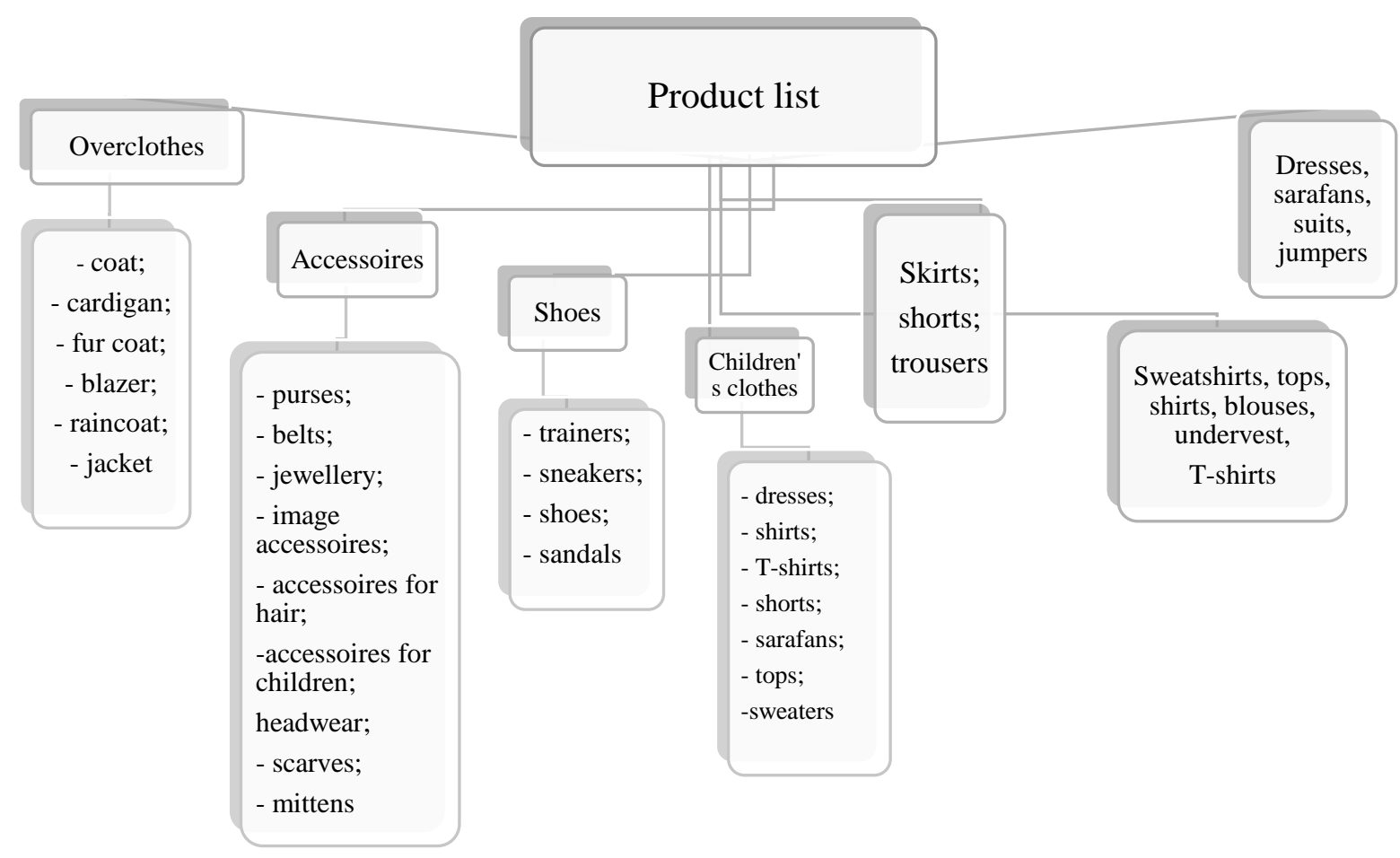

Figure 1. Production list of the company «VOVK»

The first sweatshirts which we see now, a loose-fitting sweater without a soft cotton collar, was developed under the RussellAthletics brand, which previously dealt only with sewing women's and children's underwear. In the $1950 \mathrm{~s}$. a famous photo of Marilyn Monroe appeared in a rough thick sweater [13]. Initially, the fabric for the sweatshirt was made using loopwheeled technology. The fabric was woven seamlessly on the special looms, and thanks to the special weave of the threads, it was less prone to shrinkage, more flexible and stretched. The main drawback of the technology was the low speed of production. It was possible to make material only for 8 sweatshirts on such machines, during one day. In this regard, technology has been completely substituted by mass production. In the $60 \mathrm{~s}$ of the twentieth century. soft and comfortable sweatshirts with the logos of educational institutions began to be worn by students. This university tradition has survived to this day. At the same time, famous people could be seen in sweatshirts. In 1970, sweaters were still produced from natural wool, but time did not stand still and synthetic fabrics became popular. Natural fabric lost demand, and acrylic, synthetic material came in their place. Since 2005, sweatshirts had such brands as Nike, Adidas, Harm's, Champion, Russell Athletic, Levi's, Cheap Monday, Obey, Our Legace, Dolce \& Gabbana, Emporio Armani etc. Thanks to their convenience, sweatshirts become popular not only in sport but in everyday clothing. Ukraine also follows the fashion trends, and the sweatshirt takes key positions in the Ukrainians' clothing. Particularly, sweatshirts with own captions and prints became more popular. Among sweatshirts with own prints, one should notice «name sweatshirts». There is the highest demand for women's clothing in the country, but the men's clothing segment also has a significant share in the market. 


\begin{tabular}{|c|c|c|c|c|c|c|}
\hline 2020 & 2021 & 2022 & 2023 & 2024 & 2025 & 2026 \\
\hline
\end{tabular}

\begin{tabular}{|c|}
\hline Different patterns \\
will appear \\
depending on the \\
weather (sun, \\
snowflakes, rain \\
drops)
\end{tabular}
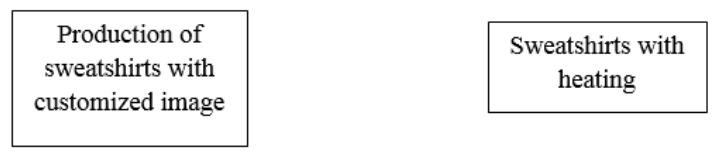

Figure 2. Roadmap for authors' product idea development

In order to create a buyer profile of the innovative sweatshirts, we use the popular persona method to help you understand who will buy our product and why they need it. Through the example of three persons (Table 1), potential buyers are analyzed in detail.

We calculate indices that will allow us to understand the sales volumes of our products and to analyze the market.

TAM as the total addressable market. In order to calculate it, it is necessary to multiply the average cost of the product by the number of people who want to buy a sweatshirt. According to official data, the population in Ukraine is 42153200 people, and those who would like to purchase a sweatshirt are about 50\%, i. e. 22153200 people. It means that TAM = $1200 \mathrm{UAH} \cdot 22153200$ persons $=26583840000 \mathrm{UAH}$.

SAM is served available market (i. e., a part of the TAM market where the observed enterprise will operate). It is calculated by multiplying the TAM index by the number of persons who also have purchasing power (20\%), in addition to desire. Then $\mathrm{SAM}=26583840000 \cdot 0.2=5316768000 \mathrm{UAH}$.

Table 1. Analysis of the target audience in the project

\begin{tabular}{|c|l|l|l|}
\hline Features & \multicolumn{1}{|c|}{ Angelina } & \multicolumn{1}{c|}{ Maksym } & \multicolumn{1}{c|}{ Kateryna } \\
\hline $\begin{array}{c}\text { What are } \\
\text { they? }\end{array}$ & $\begin{array}{l}\text { An upper-middle-class } \\
\text { student, a blogger, has her } \\
\text { own Instagram account, has } \\
\text { her own YouTube channel, } \\
\text { where she uploads various } \\
\text { videos about unpacking } \\
\text { ordered innovative things }\end{array}$ & $\begin{array}{l}\text { Modern dance teacher, who } \\
\text { has a team of young girls and } \\
\text { boys performing at various } \\
\text { parties, shows }\end{array}$ & $\begin{array}{l}\text { A young girl, wearing } \\
\text { comfortable and high- } \\
\text { quality clothing, loves to } \\
\text { stand out for the brightest } \\
\text { things in everyday life }\end{array}$ \\
\hline Goals & $\begin{array}{l}\text { To increase the number of } \\
\text { subscribers, views, reposts, } \\
\text { likes. To gain popularity }\end{array}$ & $\begin{array}{l}\text { To purchase unusual prints } \\
\text { for the team name for all its } \\
\text { members at Vovk }\end{array}$ & $\begin{array}{l}\text { To buy one universal } \\
\text { sweatshirt instead of the } \\
\text { usual one }\end{array}$ \\
\hline Doubts & $\begin{array}{l}\text { High price, non-conformity } \\
\text { of goods with their features }\end{array}$ & $\begin{array}{l}\text { The impossibility to make } \\
\text { such sweatshirts with prints, } \\
\text { a long time of production }\end{array}$ & $\begin{array}{l}\text { The fear of washing this } \\
\text { clothing that it may lose its } \\
\text { shape, will not change its } \\
\text { colour }\end{array}$ \\
\hline Conclusion & $\begin{array}{l}\text { It is necessary to add videos } \\
\text { detailing the properties of the } \\
\text { product on your own pages } \\
\text { on the Internet }\end{array}$ & $\begin{array}{l}\text { The necessity to produce } \\
\text { innovative prints with a } \\
\text { convenient time for the } \\
\text { consumer }\end{array}$ & $\begin{array}{l}\text { To add instructions for } \\
\text { applying sweatshirt }\end{array}$ \\
\hline
\end{tabular}


SOM as Serviceable \& Obtainable Market is a market share of an enterprise that can really be reached. For the calculation, it is necessary to know such values as the number of manufactured sweatshirts per month (estimated potential capacity for the production of sweatshirts - 1350 units per month, based on the daily production of sweatshirts at the small enterprises according to the [14]) and the number of months (year). That is, $\mathrm{SOM}=1350 \cdot 12=16200$ sweatshirts. According to the data, the available market volume is $26583840000 \mathrm{UAH}$, and also in the year, we will be able to produce 16200 sweatshirts. The obtained figures are quite comparable. It is possible to maintain a balance between supply and demand for sweatshirts.

The main competitors of the company at the Ukrainian market are the following brands, Table 2.

Thus, only fragmentary analysis of competitors (since there are more in Ukraine, there are leaders in the regions) the company Vovk has strong competitors, that is why in order to maintain its position in the market, it needs to produce a line of more individual customized clothing, i. e. to expand and to capture a new target segment.

In comparison with its competitor «Promin», «Vovk» does not have a lot of incentive measures, so it needs to keep in touch with consumers, perform promotions, discounts, and keep up-to-date with its clothing.

At the same time, one may confirm that «VOVK» has a number of competitive advantages, namely: the use of natural fabrics in the production of clothing, the uniqueness of design, the availability of skilled personnel, innovative approach to brand promotion, affordable prices, convenience and versatility of the offered models, customization of products, welldesigned studios and the photographic zones (the company call studios its own shops and photographic zones are located in stores for the customers' convenience, for example, if a visitor of the store is not ready to purchase clothes and wants to consult with someone, he or she may take a photo in this clothes before buying).

The goal of pricing in the implementation of the project is to increase profits and to gain leadership by product quality. Thus, we offer a prestigious prices strategy, because the product is innovative, has unique properties and has no analogues in the market. We will calculate the average size of the customer's purchase account: the proceeds per month from the sale of sweatshirts - $156000 \mathrm{UAH}$ (about 1350 products are sold per month), the number of checks per month -95 . The average check $=156000 / 95=1642 \mathrm{UAH}$.

Table 2. Main competitors on the Ukrainian clothes market

\begin{tabular}{|c|l|}
\hline Competitor & \multicolumn{1}{c|}{ Description } \\
\hline 1 & \multicolumn{1}{c|}{2} \\
\hline \multirow{5}{*}{ Must have } & $\begin{array}{l}\text { The first Ukrainian women's clothing market. The brand has appeared in the market since 2010 } \\
\text { when its founders - Anna Kovalenko and Anastasia Dziuba released their first collection. } \\
\text { Today Must Have is its own 1000 square meter production facility, 11 stores in Kyiv, Lviv, } \\
\text { Kharkiv and Odesa (including the largest shopping and entertainment centres), an online store, } \\
12 \text { collections a year and 250 talented employees. The brand assortment includes quality } \\
\text { business, evening and casual women's clothing. In order to produce clothing, the company buys } \\
\text { fabrics and accessories from industry leaders in Europe [15] }\end{array}$ \\
\hline \multirow{5}{*}{ Casual } & $\begin{array}{l}\text { It was born in the UK in her Scottish part in Aberdeen. The company presents comfortable } \\
\text { women's clothing that combines the «comfortable minimalism» inherent in street fashion, and } \\
\text { fashion trends borrowed from catwalk shows. The range includes coats, jackets, overalls, } \\
\text { dresses, skirts, pants, etc. Each type of clothing is represented by several different styles. } \\
\text { Corporate showroom is located in the centre of Kyiv [16] }\end{array}$ \\
\hline
\end{tabular}


End of table 2

\begin{tabular}{|c|l|}
\hline 1 & \multicolumn{1}{c|}{2} \\
\hline \multirow{3}{*}{ Zara } & $\begin{array}{l}\text { Spanish «fashion» brand, which produces men's, women's and children's clothing. Zara is part } \\
\text { of the Inditex Group, owned by one of Spain's richest men, the magnate Amancio Ortega. The } \\
\text { same group includes such brands as Pull and Bear, Oysho, Stradivarius, Bershka, Massimo } \\
\text { Dutti and Uterqüe. A feature of Zara clothing is the design approach while maintaining } \\
\text { democratic prices. The company is headquartered in La Coruna, Galicia, Spain. It was here } \\
\text { where the first Zara store was opened in 1975 [17] }\end{array}$ \\
\hline Promin & $\begin{array}{l}\text { The brand was created on the basis of Lviv knitwear factory «Promin». The company was } \\
\text { founded in 1939 and for over 60 years was considered a leader among the manufacturers of } \\
\text { knitwear in Eastern Europe. Promin produces casual wear collections for active leisure for the } \\
\text { whole family - women, men and children. The brand works with natural raw materials (cotton, } \\
\text { viscose), which are made exclusively to order. Brand and online stores have a loyalty program } \\
\text { for regular customers, and there are often promotions and special offers. Price segment: from } \\
\text { 130 UAH (T-shirts, T-shirts) to 960 UAH (Bombers) [18] }\end{array}$ \\
\hline Grass & $\begin{array}{l}\text { The mass-market brand was created in April 2015 by three friends Taras Volkov, Ksenia } \\
\text { Konstantinova and Sasha Kolibabchuk. The idea came up in February, and three months later, } \\
\text { the first collection of the brand, consisting of five models of women's clothing, appeared. At } \\
\text { that time, the main sales channels were social networks and the site. The successful launch gave } \\
\text { the brand the opportunity to open its own store in the heart of Kyiv - at Kostyolnaya Street, } 6 \\
\text { (near Independence Square). Today, the GRASS brand releases 4 major collections per year } \\
\text { and is working on collaborations with other brands [19] }\end{array}$ \\
\hline
\end{tabular}

In order to implement an innovative project, there is a need to upgrade an existing company. The startup team will initially consist of six persons, particularly: two project managers, two technical engineers, a tailor, and a designer.

The consumers' buying behaviour and the number of profits generated from the sale of sweatshirts will be most influenced by such factors as price of goods and consumers' financial standing, seasonality, level of consumers' awareness, professionalism of sales staff, permanent availability of the required size of the product, the possibility of different payment methods, availability of goods discounts, the existence of substitute goods (for example, usual sweatshirts). The company will receive more profit in April, May, June, July, as well as in September as this is influenced by the seasonality factor. Between October and February, there will be a relative decline in sales, but in March the product will again start to enjoy considerable popularity.

Planned marketing practices for innovative sweatshirts:

1) Online store - https://vovk.com/;

2) Social networks - Instagram та Facebook;

3) Own brand stores.

In order to promote innovative products in the market, we offer the following marketing tools [20], table 3-4.

Table 3. Marketing activities for promoting innovative technology in the Ukrainian market (advertising)

\begin{tabular}{|l|l|l|}
\hline \multicolumn{1}{|c|}{ Tool } & \multicolumn{1}{|c|}{ Description } & \multicolumn{1}{|c|}{ Expences } \\
\hline 1 & \multicolumn{1}{|c|}{2} & \multicolumn{1}{|c|}{3} \\
\hline $\begin{array}{l}\text { Advertisement on the } \\
\text { Internet (Facebook, } \\
\text { Instagram, YouTube) }\end{array}$ & $\begin{array}{l}\text { Videos of the user manual, pictures of the } \\
\text { product and information about it will be } \\
\text { posted on own pages on social networks and } \\
\text { with the help of bloggers }\end{array}$ & $25000 \mathrm{UAH}$ per year \\
\hline $\begin{array}{l}\text { Creation of landing } \\
\text { page }\end{array}$ & $\begin{array}{l}\text { The page where visitors will be able to } \\
\text { obtain product information, contact the } \\
\text { seller to order it }\end{array}$ & 4 500 UAH [21] \\
\hline
\end{tabular}


End of table 3

\begin{tabular}{|l|l|l|}
\hline 1 & \multicolumn{1}{|c|}{2} & \multicolumn{1}{|c|}{3} \\
\hline Advertising in media & $\begin{array}{l}\text { 1. Magazines for own stores (35 pcs); } \\
\text { 2. In periodicals (magazines) about the } \\
\text { latest fashions }\end{array}$ & $\begin{array}{l}\text { 1. One journal production costs } \\
\text { 600 UAH. Total expenses per } \\
\text { month - 21 000 UAH; } \\
\text { 2. For example, advertising in one } \\
\text { issue for the magazine «ELLE» is } \\
\text { from 79 000 UAH [22] }\end{array}$ \\
\hline External advertising & $\begin{array}{l}\text { For example, the cost of advertising } \\
\text { billboards in Kharkiv - from 4 000 } \\
\text { points of sale }\end{array}$ \\
\hline
\end{tabular}

Thanks to advertising campaigns and promotional activities, Vovk will be able to increase sales, capture market share, gain consumer loyalty, and enhance the company's image.

Table 4. Marketing activities for promote innovative technology in the Ukrainian market (sales promotion)

\begin{tabular}{|c|l|}
\hline Tool & \multicolumn{1}{|c|}{ Description } \\
\hline \multirow{3}{*}{ Sales } & $\begin{array}{l}\text { 1. } 10 \% \text { off for the first } 50 \text { buyers in the online store (every month). } \\
\text { 2.7\% off on the purchase of three sweatshirts, 10\% off on the purchase of } \\
\text { six units; sales before Holidays on Black Friday at Cyber Mondays at own } \\
\text { stores }\end{array}$ \\
\hline Lottery & $\begin{array}{l}\text { The buyer's check will have the number of the participant by which he or she } \\
\text { will be able to win a gift (accessories or clothing presented in the company's } \\
\text { assortment) }\end{array}$ \\
\hline Free guarantee certificates & Warranty certificate for the product, valid for 6 months \\
\hline \multirow{2}{*}{ Souvenir goods } & $\begin{array}{l}\text { When the buyer purchases a sweatshirt, he or she gets as a gift, for example, a } \\
\text { pen, a notepad, a cup or a calendar with the Vovk logo (in the initial stages } \\
\text { when innovative products are launched) }\end{array}$ \\
\hline
\end{tabular}

In addition, the costs of materials, equipment, workers' salaries, tax payments, utility bills, and transportation costs should be highlighted among other project implementation costs.

The main risks of this innovative project: the product will not be in demand; technical problems when using it; the appearance of additional costs; implementation of the idea regarding goods by competitors; failure in employees' duties; delay of project implementation deadlines; refusal of the head of the company «Vovk» to implement the idea.

Having identified the main potential risks that may arise during the project implementation, it is necessary to evaluate them by two matrices based on the use of such indices as the probable risk (Table 5) and the possible consequences of its occurrence (Table 6). After identifying the risks, we analyze them by comparing the consequences and the probability of the risk occurring in Table 7.

Table 5. Risk probability evaluation matrix

\begin{tabular}{|c|l|l|}
\hline Level & \multicolumn{1}{|c|}{ Decoding of the level } & \multicolumn{1}{c|}{ Description } \\
\hline A & Almost certainly & The risk is likely to arise in most cases \\
\hline B & Probably & The risk is likely to arise in most cases \\
\hline C & Maybe & The risk must arise under certain conditions \\
\hline D & Hardly & The risk may arise under certain conditions \\
\hline E & It is unlikely & Risk can only arise in exceptional circumstances \\
\hline F & Never & There will be no risk \\
\hline
\end{tabular}


Table 6. Matrix for assessing the consequences of risk

\begin{tabular}{|c|l|l|}
\hline Level & Decoding & \multicolumn{1}{c|}{ Description } \\
\hline 1 & Minor & $\begin{array}{l}\text { Minor impact on project implementation; no unfavourable advertising; no conflict } \\
\text { between the parties; minimal impact on the environment; budgetary impact does } \\
\text { not exceed 1\% }\end{array}$ \\
\hline 2 & The minimum & $\begin{array}{l}\text { Minimal impact on project implementation; slight loss of the concerned parties' } \\
\text { trust; moderate impact on the environment; budgetary impact ranges from 1\% to } \\
2.5 \%\end{array}$ \\
\hline 3 & Moderate & $\begin{array}{l}\text { The implementation of the project is delayed by less than 20\% of the initial } \\
\text { implementation period; significant medium-term environmental impact; budgetary } \\
\text { impact ranges from 2.5\% to 10\% }\end{array}$ \\
\hline 5 & Significant & $\begin{array}{l}\text { The implementation of the project is delayed more than 20\% of the initial } \\
\text { implementation period; significant long-term impact on the environment; } \\
\text { budgetary impact ranges from 10\% to 20\% }\end{array}$ \\
\hline 5 & Catastrophic & $\begin{array}{l}\text { Implementation of the project under threat; significant long-term impact on the } \\
\text { environment; budgetary impact exceeds 20\% }\end{array}$ \\
\hline
\end{tabular}

Table 7. Matrix «probability - possible consequences»

\begin{tabular}{|c|c|c|c|c|c|}
\hline \multirow{2}{*}{ Probability } & \multicolumn{5}{|c|}{ Consequences } \\
\cline { 2 - 6 } & $\mathbf{1}$ & $\mathbf{2}$ & $\mathbf{3}$ & $\mathbf{4}$ & $\mathbf{5}$ \\
\hline A & M & H & H & E & E \\
\hline B & M & M & H & H & E \\
\hline C & L & M & M & H & H \\
\hline D & L & L & M & M & H \\
\hline E & L & L & L & M & M \\
\hline
\end{tabular}

E (Extreme) - unacceptable risk; detailed research and regulation planning at higher levels;

$\mathrm{H}$ (High) - high risk; the attention of higher executives is required;

M (Medium) - moderate risk; executives should be responsible;

L (Low) - low risk; regulation of the routine procedures.

According to the tables, we analyze the potential risks in the implementation of the project (Table 8).

Based on the table, we can conclude that the moderate risk is that the product will not be in demand. High risks include the appearance of additional costs; delay of project implementation time; the Vovk head's refusal to realize the idea. Low risks indicate that they are unlikely to occur, but they should be taken into account.

The evaluation of the effective indices of the innovation project provides the following table (Table 9). It is taken into account that the cost reduction rate is $13.5 \%$ according to the NBU discount rate [24].

Table 8. Evaluation of potential risks

\begin{tabular}{|l|l|c|c|c|}
\hline № & \multicolumn{1}{|c|}{ Risk } & Probability & Consequences & Level of the risk \\
\hline 1 & The product will not be in demand & D & 4 & Medium \\
\hline 2 & The technical problems in the use by consumers & E & 3 & Low \\
\hline 3 & The appearance of additional costs & A & 2 & High \\
\hline 4 & $\begin{array}{l}\text { The realization of the idea of the goods by } \\
\text { competitors }\end{array}$ & E & 2 & Low \\
\hline 5 & Failure in duties of employees & E & 3 & Low \\
\hline 6 & Delay of the project implementation deadline & C & 4 & High \\
\hline 7 & Vovk’s head refuses to implement the idea & D & 5 & High \\
\hline
\end{tabular}


The obtained figures indicate that the project is commercially profitable. It is attractive given the high net consolidated revenue ratio. A high profitability index for the project is planned. The payback period is short enough, so the company has every chance quickly to pay back the costs to bring innovative products to the market and to earn a steady profit from the sale of the product - unique sweatshirts that can change colour depending on weather conditions.

Table 9. The results of the calculations of potential project economic effectiveness for production and implementation of innovative sweatshirts

\begin{tabular}{|l|c|}
\hline \multicolumn{1}{|c|}{ Efficiency index, units } & Index \\
\hline Net income & 80300 \\
\hline Profitability Index, \% & 140.7 \\
\hline Simplified payback period, years & 0,36 \\
\hline Payback period, taking into account the factor of time, years & 0.4 \\
\hline
\end{tabular}

Conclusions. Thus, the idea of production and further commercialization of unique trade offer - innovative sweatshirts with changing colour technology depending on external weather conditions was developed and proposed in the Ukrainian market. The introduction of this innovation was observed as an example of the national leading clothing brand «VOVK». For this company, such extension of the product offer will serve as a success factor, which will increase the potential consumers' interest in the whole range of the company, as well as create a positive image of the manufacturer, which follows the latest trends in the industry.

The authors completed a number of the following stages of the future idea implementation, such as, the target market analyses, the main competitors determination, suggestions concerning tentative portrait of the target audience, pricing strategy, methods of marketing and promotion of innovation.

The important component of the given investigation, its specificity was the identification of innovation risks with the description of their occurrence probability. The authors estimated the efficiency indices of the project, which are highlighted in the paper as the resulting table.

The carried out investigation and its visual representation is relevant for entrepreneurs engaged in tailoring and promoting their own brands in the Ukrainian market, for people interested in fashion market innovations, as well as for researches analyzing determinants and imperatives of the national innovative economy development

Directions for further research. Further researches should be focused on increasing the role of marketing in fashion, particularly in branding. The authors' attention will be focused on determining the role of the fashion market in shaping favorable national brand. From this point of view, it is interesting to determine the level of Ukrainian fashion influence on the general perception of Ukrainians among residents of other countries.

\section{References}

1. Vorona T. Startup per million. Vyd-vo "Vivat", 2018. 224 p.

2. Cherniak E. Big Money. Big Money. Principles of the first. Izd-vo "Fors", 2018. 272 p.

3. Kusumano M. A. Genius strategies. Top five lessons from Bill Gates, Andy Grove and Steve Jobs. Vyd-vo "Knyzhkovyi klub "Klub simeinoho dozvillia", 2017. 256 p.

4. Nait F. Shoes-being. Nike story told by its founder. Vyd-vo "Nash format", 2017. 432 p.

5. Shults H. History of Starbucks. Vyd-vo "Nash format", 2017. 408 p.

6. Stoun B. Upstarts. Uber, Airbnb, and the Silicon Valley battle. Vyd-vo "Nash format", 2018. 384 p.

7. Aerochromics: wear the air. URL: http://aerochromics.com/.

8. Gardabhadze I. A. Innovations in fashion design: evaluation, management, efficiency. Bulletin of KhDADM, 2014. № 6. P. 16-19.

9. Yasynska O. G. Formation of conceptual-categorical tools of management of enterprises of the fashion industry. Manager, 2018. № 2 (79). P. 181-191.

10. Chuprina N. V. Segmentation of fashion lines in the structure of the fashion industry. Bulletin of KhDADM, 2014. № 1. P. 33-38.

11. Bondarenko S. M., Palagin Yu. O., Bondarenko B. S. Improvement of assortment policy of trade enterprise in the field of fashion. Economy and society. 2018. № 16. P. 264-269. 
12. Pix - the first smart animated backpack. URL: https://peremoga.space/pix-перший-смарт-анімаційнийрюкзак.

13. Sweatshirt: yesterday, today, tomorrow. URL: https://www.oasiscatalog.com/blog/ tolstovka-vcherasegodnya-zavtra/.

14. Production of hoodies as a profitable business. URL: https://biznes-prost.ru/proizvodstvo-tolstovok-kakvygodnyj-biznes.html.

15. Must have. URL: https://musthave.ua/?gclid=Cj0KCQiA6IHwBRCJARIsALNjViURn-YMli9_yM34ZM jHZv5h8JV7HYLG1ZmnecBZuUAC-OD9J0vyEekaAqhUEALw_wcB.

16. Casual. URL: https://casualua.com.ua/.

17.Zara. URL: https://uk.m.wikipedia.org/wiki/Zara.

18. Promin. URL: https://promin.ua/.

19. Grass. URL: https://vsisvoi.ua/brands/grass.

20. Bozhkova V. V., Ptashchenko O. V., Saher L. Yu., Syhyda L. O. Transformation of marketing communications tools in the conditions of globalization. Marketing and Management of Innovations, 2018. № 1. P. 72-82. https://doi.org/10.21272/mmi.2018.1-05

21. How much is a landing page? Landing Page (single page site) price in Ukraine. URL: https://my-master. net.ua/stoimost-price-landing-page/.

22. Advertising in the media. URL: https://media.adv-sonata.com/press/zhenskie/elle/.

23. Outdoor advertising in Kiev and Ukraine. URL: https://pilum24.com.ua/nar?gclid=CjwKCAiA3uDwBR BFEiwA1VsajKSyPDrHAQP0Y_BaTHVgihLdAsQLQhl4DhDhdQzxBRsyWZDB132KKhoCiOUQAvD BwE.

24. NBU discount rate (as of 10 January 2020). URL: https://index.minfin.com.ua/ua/banks/nbu/refinance/.

\section{Список використаної літератури}

1. Ворона Т. Стартап на мільйон / пер. Г. Сологуб. Видавництво «Віват», 2018. 224 с.

2. Черняк E. Big Money. Принципы первых. Изд-во «Форс», 2018. 272 с.

3. Кусумано М. А. Стратегії геніїв. П'ять найважливіших уроків від Білла Гейтса, Енді Гроува та Стіва Джобса. Вид-во «Книжковий клуб «Клуб сімейного дозвілля», 2017. 256 с.

4. Найт Ф. Взуття-буття. Історія Nike, розказана їі засновником. Вид-во «Наш формат», 2017. 432 с.

5. Шульц Г. Історія Starbucks. Вид-во «Наш формат», 2017. 408 с.

6. Стоун Б. Вискочки. Uber, Airbnb та битва за Кремнієву долину. Вид-во «Наш формат», 2018. 384 с.

7. Aerochromics: wear the air. URL: http://aerochromics.com/.

8. Гардабхадзе І. А. Інновації у фешн-дизайні: оцінка, управління, ефективність. Вісник ХДАДМ. 2014. № 6. C. 16-19.

9. Ясинська О. Г. Формування понятійно-категоріального інструментарію менеджменту підприємств індустрії моди. Менеджер. 2018. № 2 (79). С. 181-191.

10. Чупріна Н. В. Сегментація ліній модного одягу в структурі індустрії моди. Вісник ХДАДМ. 2014. № 1. С. 33-38.

11. Бондаренко С. М., Палагін Ю. О., Бондаренко Б. С. Удосконалення асортиментної політики торговельного підприємства у сфері моди. Економіка і суспільство. 2018. Випуск 16. С. 264-269.

12.Pix - перший смарт-анімаційний рюкзак. URL: https://peremoga.space/pix-перший-смартанімаційний-рюкзак.

13. Толстовка: вчера, сегодня, завтра. URL: https://www.oasiscatalog.com/blog/tolstovka-vchera-segodnyazavtra/.

14. Производство толстовок как выгодный бизнес. URL: https://biznes-prost.ru/proizvodstvo-tolstovokkak-vygodnyj-biznes.html.

15. Must have URL: https://musthave.ua/?gclid=Cj0KCQiA6IHwBRCJARIsALNjViURn-YMli9_yM34ZMj HZv5h8JV7HYLG1ZmnecBZuUAC-OD9J0vyEekaAqhUEALw_wcB.

16. Casual. URL: https://casualua.com.ua/.

17. Zara. URL: https://uk.m.wikipedia.org/wiki/Zara.

18. Promin. URL: https://promin.ua/.

19. Grass. URL: https://vsisvoi.ua/brands/grass.

20. Божкова В. В., Птащенко О. В., Сагер Л. Ю., Сигида Л. О. Трансформації інструментарію маркетингових комунікацій в умовах глобалізації. Маркетинг і менеджмент інновацій. 2018. № 1. C. 73-82. https://doi.org/10.21272/mmi.2018.1-05

21. Сколько стоит лендинг пейдж? Цена Landing Page (одностраничного сайта) в Украине. URL: https://my-master.net.ua/stoimost-price-landing-page/.

22. Реклама в СМИ. URL: https://media.adv-sonata.com/press/zhenskie/elle/.

23. Размещение наружной рекламы в Киеве и по Украине. URL: https://pilum24.com.ua/nar?gclid= CjwKCAiA3uDwBRBFEiwA1VsajKSyPDrHAQP0Y_BaTHVgihLdAsQLQhl4DhDhdQzxBRsyWZDB 132KKhoCiOUQAvD_BwE.

24. Облікова ставка НБУ (станом на 10.01.2020 p.). URL: https://index.minfin.com.ua/ua/banks/nbu/ refinance/. 